ISSN 2080-1653

DOI 10.24917/20801653.322.14

\author{
JOANNA DOMINIAK \\ Uniwersytet im. Adama Mickiewicza w Poznaniu, Polska \\ Adam Mickiewicz University in Poznan, Poland
}

\title{
Poziom rozwoju nowoczesnych usług w Polsce. Ujęcie regionalne
}

\section{The Level of Modern Services Development in Poland. Regional Approach}

Streszczenie: Działalność usługowa, będąca istotną częścią współczesnej gospodarki, podlega nieustannym zmianom. Zmiany te uwarunkowane są procesami ekonomicznymi, które są skutkiem m.in. postępu technologicznego, nasilającego się procesu globalizacji i zwiększającej się konkurencyjności. Artykuł ma na celu: (1) identyfikację nowoczesnych usług w oparciu o współczesną literaturę przedmiotu, (2) scharakteryzowanie poziomu rozwoju nowoczesnych usług w Polsce na tle innych państw Unii Europejskiej, (3) zanalizowanie zróżnicowania poziomu rozwoju nowoczesnych usług w Polsce w ujęciu regionalnym. Dane wykorzystane w analizie pochodzą z banku danych lokalnych Głównego Urzędu Statystycznego oraz Eurostatu. W analizie zastosowano również wskaźnik syntetyczny Perkala oraz analizę skupień. Wyniki przeprowadzonych badań prowadzą do następujących wniosków. W ujęciu całościowym wysokim poziomem rozwoju nowoczesnych usług charakteryzują się województwa: mazowieckie, małopolskie, dolnośląskie i pomorskie. Wysoka pozycja województwa mazowieckiego jest wynikiem jego najwyższej pozycji w większości analizowanych kategorii usług nowoczesnych (poza edukacyjnymi i medycznymi). Województwo małopolskie znalazło się w tej klasie głównie za sprawą wysokiego poziomu rozwoju usług edukacyjnych i badawczo-rozwojowych, a województwa dolnośląskie i pomorskie - dzięki usługom profesjonalnym. Niskim poziomem usług nowoczesnych cechują się przede wszystkim słabe gospodarczo województwa Polski Wschodniej oraz województwa: lubuskie, świętokrzyskie i opolskie. Regionalny rozkład wartości wskaźnika syntetycznego poziomu rozwoju usług nowoczesnych w wyraźny sposób nawiązuje do rozkładu ogólnego poziomu rozwoju społeczno-gospodarczego województw. Szczegółowe potwierdzenie tej relacji wymaga jednak dodatkowych badań.

\footnotetext{
Abstract: Service activity, which is an essential part of the modern economy, is constantly changing. These changes are conditioned by economic processes resulting, among others, from technological progress, the growing globalization process and increasing competitiveness. The aim of the article is: (1) to identify modern services (based on contemporary literature on the subject), (2) characteristics of the level of development of modern services in Poland compared to other European Union countries, (3) analysis of the level of development of modern services in Poland in regional approach. Data used in the analysis come from the local data bank of the Central Statistical Office and Eurostat. The Perkal synthetic index and cluster analysis were used. The results of the research lead to the following conclusions. In a comprehensive perspective, the following voivodeships are characterized by a high level of development of modern services: Masovian, Lesser Poland, Lower Silesian and Pomeranian. The high position of the Masovian voivodeship is the result of its highest position in the majority of the analyzed categories of modern services (except education and medical). The Lesser Poland voivodeship was in this class mainly due to the high level of development of educational and R\&D services, and the Lower Silesian and Pomeranian voivodships - thanks to professional
} 
services. The low level of modern services is primarily characterized by economically weak voivodeships of Eastern Poland and voivodeships: Lubusz, Świętokrzystkie and Opole. The regional distribution of the value of the synthetic level indicator for the development of modern services clearly refers to the distribution of the general level of socio-economic development of the voivodeships. Detailed confirmation of this relationship requires additional research.

Słowa kluczowe: nowoczesne usługi; Polska; rozwój; województwa

Keywords: development; modern services; Poland; voivodeships

Otrzymano: 18 grudnia 2017

Received: 18 December 2017

Zaakceptowano: 23 maja 2018

Accepted: 23 May 2018

Sugerowana cytacja / Suggested citation:

Dominiak, J. (2018), Poziom rozwoju nowoczesnych usług w Polsce. Ujęcie regionalne. Prace Komisji Geografii Przemysłu Polskiego Towarzystwa Geograficznego, 32(2), 204-215. https://doi.org/10.24917/ 20801653.322.14

\section{WSTĘP}

Działalność usługowa, będąca istotną częścią współczesnej gospodarki, podlega nieustannym zmianom. Zmiany te uwarunkowane są procesami ekonomicznymi, które są skutkiem m.in. postępu technologicznego, nasilającego się procesu globalizacji i zwiększającej się konkurencyjności. Zgodnie z teoriami działalności usługowej, coraz większego znaczenia nabierają usługi wyspecjalizowane, zatrudniające pracowników o wysokich kwalifikacjach zawodowych, wśród nich dynamicznie rozwijające się usługi o wysokim nasyceniu wiedzą. Do ich rozwoju przyczynił się także wzrost zapotrzebowania na nowoczesne usługi w dobie rozwoju gospodarki opartej na wiedzy. Artykuł ma na celu: (1) identyfikację nowoczesnych usług w oparciu o współczesną literaturę przedmiotu, (2) scharakteryzowanie poziomu rozwoju nowoczesnych usług w Polsce na tle innych państw Unii Europejskiej, (3) zanalizowanie zróżnicowania poziomu rozwoju usług nowoczesnych w Polsce w ujęciu regionalnym. Dane wykorzystane w analizie pochodzą z banku danych lokalnych Głównego Urzędu Statystycznego oraz Eurostatu.

\section{USŁUGI NOWOCZESNE I ICH ROLA W ROZWOJU W ŚWIETLE LITERATURY PRZEDMIOTU}

W literaturze przedmiotu równolegle funkcjonują pojęcia: usługi nowe, usługi innowacyjne, a także usługi nowoczesne. Pojęcia te, choć nie są synonimami, często używane są zamiennie. Warto jednak zwrócić uwagę, że pod pojęciem usług nowych rozumie się zwykle te usługi, które pojawiły się stosunkowo niedawno. Nowość bowiem to (według słownika języka polskiego) coś właśnie wynalezionego, zrobionego, będącego od niedawna w jakimś środowisku. $W$ tym miejscu należy też rozgraniczyć nowość w skali przedsiębiorstwa (skala mikro) oraz nowość na rynku (skala makro). Coś, co będzie nowością dla jednego przedsiębiorstwa, może już od dawna funkcjonować w innym. Podobnie w skali makro. Warto więc mieć na uwadze fakt, że coś może być nowością lub nie ze względu na punkt odniesienia. Możliwość zamawiania zakupów drogą elektroniczną w przypadku wielu sklepów w Polsce jest usługą nową, choć przecież sklepy 
oferowały już sprzedaż internetową w wielu krajach Europy Zachodniej czy w Stanach Zjednoczonych.

L. Menor, M. Tatikonda i S. Sampson (2002) definiują nową usługę jako ofertę, która wcześniej nie była dostępna dla klientów firmy i wynika z dodania jej do wcześniejszej oferty usług lub ze zmian w koncepcji usług, które pozwalają na ich udostępnianie. Ponieważ w literaturze przedmiotu usługę postrzega się jako szereg interakcji pomiędzy uczestnikami, procesami i elementami materialnymi, zmiany któregokolwiek elementu powodują „nowość” usługi. Zdaniem autorów wszystkie zmiany w koncepcji usługi, które wymagają innych kompetencji niż dotychczasowe, mogą być uważane za nową usługę. Autorzy podkreślają także, że należy brać pod uwagę zarówno „nowość" oferty usługowej (jaka nowa usługa jest oferowana), jak i zmiany w koncepcji usługi (jak jest oferowana). Takie podejście wymaga jednak podziału usług nowych ze względu na stopień dokonanych zmian. Nowe usługi, podobnie jak usługi innowacyjne, mogą być klasyfikowane ze względu na stopień nowości na radykalne i przyrostowe. Radykalne dotyczą nowych usług dla rynku, wcześniej niezdefiniowanych, najczęściej powstałych w wyniku rozwoju ICT, bądź też nowych usług w przedsiębiorstwie, które jednak świadczone są już na rynku przez inne przedsiębiorstwa. Przyrostowe zaś dotyczą wzbogacenia istniejącej oferty usług przez dodanie nowych pozycji (np. w menu, nowych tras, kursów), zmian w cechach usług dotychczas już świadczonych czy niewielkich zmian, które mają wpływ na ich odbiór przez klientów (Johnson, Menor, Roth, Chase, 2000; Menor, Tatikonda, Sampson, 2002). Nowe usługi mogą być także klasyfikowane ze względu na to, czy „nowość” dotyczy wkładu (input), procesu, czy efektu (output).

Innowacyjność w odniesieniu do nowości jest pojęciem szerszym. Obejmuje ono cały proces przejścia od pomysłu, przez jego realizację, aż do wprowadzenia nowości w funkcjonowaniu przedsiębiorstwa. Innowacja jest więc komercyjnym zastosowaniem czegoś nowego (nowości). Podobnie jak w przypadku nowości, także innowacje rozpatrywać można w różnych skalach. W zależności od punktu odniesienia usługa może być innowacyjna dla przedsiębiorstwa lub na rynku (jeśli wcześniej nie wprowadziło jej żadne przedsiębiorstwo). Podobnie jak w przypadku innowacji produktowych, w przypadku usług także mamy do czynienia z dwoma rodzajami innowacji. W zależności od rozpatrywanej skali możemy je podzielić na radykalne (radical) i przyrostowe (incremental) (Garcia, Calantone, 2002) Innowacje radykalne to nowe usługi na rynku, wcześniej nieznane, niezdefiniowane, powstające najczęściej w wyniku zastosowania nowych technologii (szczególnie w sektorze ICT). Innowacje przyrostowe polegają najczęściej na rozszerzeniu istniejącej oferty usług przez dodanie nowych elementów, zmiany form dystrybucji. Zwykle (podobnie jak w przypadku produktów) innowacje usługowe o charakterze radykalnym mają charakter innowacji podażowych (i powstają dzięki rozwojowi ICT), a innowacje przyrostowe - popytowych, które są narzucane przez oczekiwania klientów.

Usługi nie są jednakowo podatne na innowacje. Dyfuzja postępu technologicznego w usługach charakteryzuje się nierównomiernością jego rozprzestrzeniania się w różnych rodzajach usług. Wynika to z heterogeniczności i związanych z nią odmiennych prawidłowości rozwoju poszczególnych usług i roli, jaką w nich odgrywają praca i kapitał (Szukalski, 2001). W literaturze odnajdujemy wiele klasyfikacji usług ze względu na stopień podatności na innowacje, jak choćby „sectoral innovation styles typology” 
(Soete, Miozzo, 1989) czy „sectoral innovation patterns typology” (Den Hertog, Bilderbeek, 1999), a w polskiej literaturze przedmiotu podział K. Rogozińskiego (2004). Generalnie przeważa w nich pogląd, że mniejszą podatnością na innowacje cechują się usługi suplier oriented, czyli zorientowane na dostawcę - usługi osobiste, hotele i restauracje, handel. Zdecydowanie większą podatnością na innowacje cechują się usługi oparte na wiedzy i związane z obsługą działalności gospodarczej. W kontekście podatności usług na innowacje należy także wspomnieć o kategorii usług bazujących na wiedzy (opartych na wiedzy), knowledge intensive services. Są to usługi, których ważnym elementem jest wiedza, stanowiąca ich źródło (input). Istotna jest także możliwość wykorzystania wyniku procesu lub czynności usługowej jako wkładu do procesu produkcyjnego. Stąd więc ich wysoka podatność na zmiany i innowacje.

Pojęcie „usługa nowoczesna” (modern service) ma nieco inny wymiar. Większe znaczenie przypisuje się tu postępowi technologicznemu (Mishra, Lundstromm, Anand, 2011). Nowoczesny to postępowy, jak sama nazwa wskazuje - właściwy nowym czasom. Stąd w dobie dynamicznego rozwoju ICT i wzrostu znaczenia w gospodarce wiedzy sensownym wydaje się być wybór polegający na przyjęciu za usługi nowoczesne takich usług, które zalicza się do usług wiedzochłonnych (opartych na wiedzy) i dodatkowo „właściwych nowym czasom”, czyli podlegających dynamicznemu rozwojowi. Wśród klasyfikacji usług na tradycyjne i nowoczesne często pojawia się także kryterium dynamiki wzrostu udziału usług w tworzeniu PKB. Przykładem tego typu podejścia jest klasyfikacja B. Eichengreena (2009). Wyróżnia on:

- usługi tradycyjne (handel, transport i magazynowanie, administracja), których udział w tworzeniu PKB spada,

- usługi stanowiące hybrydę usług nowoczesnych i tradycyjnych (edukacja, opieka zdrowotna, hotele i restauracje, usługi komunalne i osobiste) - ich udział rośnie powoli,

- usługi nowoczesne (pośrednictwo finansowe, informatyka, usługi dla biznesu, komunikacja), których udział wzrasta bardzo dynamicznie.

$\mathrm{Z}$ tego względu drugim przyjętym kryterium wyróżniającym usługi nowoczesne jest ich dynamiczny rozwój mierzony wzrostem ich udziału w strukturze usług (według udziału w tworzeniu dochodu i zatrudnienia) oraz dynamiką zatrudnienia. Nakładając na siebie te dwa kryteria, dokonano identyfikacji nowoczesnych usług, które zostaną poddane szczegółowej analizie w dalszej części opracowania. W oparciu o wcześniej przywołaną literaturę przedmiotu, w pracy, dla potrzeb analizy empirycznej, jako usługi nowoczesne traktuje się więc takie usługi, które spełniają dwa kryteria. Po pierwsze założono, że są to usługi należące do grupy tzw. usług o wysokim nasyceniu wiedzą (KIS). Przyjęcie tego założenia ma tę zaletę, że usługi te występują w oficjalnych klasyfikacjach działalności (NACE, PKD), dzięki czemu możliwe jest pozyskanie danych statystycznych niezbędnych do analizy. Drugim przyjętym kryterium wyróżniającym usługi nowoczesne jest ich dynamiczny rozwój wyrażający się wzrostem ich udziału w strukturze usług według miernika zatrudnienia. Nałożenie na siebie tych dwóch kryteriów pozwala na wyróżnienie rodzajów działalności usługowych, które zostaną poddane szczegółowej analizie w dalszej części opracowania. Należą do nich usługi: informatyczne, badawczo-rozwojowe, obsługa nieruchomości, profesjonalne, finansowo-ubezpieczeniowe oraz edukacyjne i medyczne (tab. 1). Tego typu podejście ma podstawową zaletę - pozwala na prowadzenie analiz empirycznych w oparciu o publikowane 
dane statystyczne. Przyjęcie takich założeń nie jest także pozbawione mankamentów. Przede wszystkim nie uwzględnia ważnej grupy - niewątpliwie nowoczesnych usług które nie zostały sklasyfikowane w NACE (PKD). Chodzi np. o usługi elektroniczne, takie jak: elektroniczna administracja, zdalna medycyna, elektroniczny handel czy elektroniczna bankowość.

Tab. 1. Usługi nowoczesne

\begin{tabular}{|l|c|c|}
\hline \multicolumn{1}{|c|}{$\begin{array}{c}\text { Usługi oparte na wiedzy (KIS - knowledgwe intensive services) - } \\
\text { według PKD }\end{array}$} & Kryterium 1 & Kryterium 2 \\
\hline Działalność pocztowa i telekomunikacyjna & $\mathrm{V}$ & - \\
\hline Informatyka i działalność pokrewna & $\mathrm{V}$ & $\mathrm{V}$ \\
\hline Działalność badawczo-rozwojowa & $\mathrm{V}$ & $\mathrm{V}$ \\
\hline Transport wodny i powietrzny & $\mathrm{V}$ & - \\
\hline Obsługa nieruchomości & $\mathrm{V}$ & $\mathrm{V}$ \\
\hline Usługi profesjonalne & $\mathrm{V}$ & $\mathrm{V}$ \\
\hline Pośrednictwo finansowe i ubezpieczenia & $\mathrm{V}$ & $\mathrm{V}$ \\
\hline Edukacja & $\mathrm{V}$ & $\mathrm{V}$ \\
\hline Opieka zdrowotna & $\mathrm{V}$ & $\mathrm{V}$ \\
\hline Działalność sportowa, kulturalna i rekreacyjna & $\mathrm{V}$ & - \\
\hline
\end{tabular}

Kryteria:

1. Należą do usług o wysokim nasyceniu wiedzą (knowledge intensive services - KIS).

2. Cechują się wzrostem udziału w strukturze usług (według miernika zatrudnienia).

Źródło: opracowanie własne

\section{Poziom RozWoju NOWOCZESNYCH USŁUG W POLSCE}

Punktem wyjścia niniejszej analizy była próba ukazania poziomu rozwoju nowoczesnych usług w Polsce na tle innych państw Unii Europejskiej. Na tym etapie postępowania badawczego wykorzystano cechy zamieszczone w tabeli 2, opisujące poszczególne zidentyfikowane usługi nowoczesne.

Tab. 2. Wskaźniki poziomu rozwoju nowoczesnych usług

\begin{tabular}{|l|l|}
\hline \multicolumn{1}{|c|}{ Rodzaj usług } & \multicolumn{1}{|c|}{ Wskaźniki działalności usługowej } \\
\hline \multirow{4}{*}{ Usługi edukacyjne i medyczne } & wydatki na edukację jako \% PKB \\
\cline { 2 - 2 } & wskaźnik skolaryzacji (szkoły wyższe) \\
\cline { 2 - 2 } & odsetek osób korzystających z e-learningu \\
\cline { 2 - 2 } & wydatki na ochronę zdrowia na 1 mieszkańca (euro) \\
\cline { 2 - 2 } & personel medyczny na 100 tys. mieszkańców \\
\hline \multirow{4}{*}{ Usługi badawczo-rozwojowe } & odsetek pracujących w B+R w aktywnych zawodowo \\
\cline { 2 - 2 } & wydatki ogółem na B+R (GERD) - na 1 mieszkańca (euro) \\
\cline { 2 - 2 } & wydatki przedsiębiorstw - na B+R (BERD) na 1 mieszkańca (euro) \\
\hline \multirow{3}{*}{ Usługi profesjonalne } & odsetek pracujących w sekcji: pośrednictwo finansowe \\
\cline { 2 - 2 } & liczba instytucji kredytowych na 1 tys. podmiotów gospodarczych \\
\cline { 2 - 2 } & odsetek zatrudnionych w instytucjach kredytowych \\
\hline & odsetek pracujących w sektorze ICT \\
\cline { 2 - 2 } & odsetek zatrudnionych w usługach profesjonalnych (sekcja M) \\
\hline
\end{tabular}

Źródło: opracowanie własne 
W analizie zróżnicowania przestrzennego poziomu rozwoju nowoczesnych usług zastosowano syntetyczny wskaźnik Perkala ${ }^{1}$ w następującej postaci (Kostrubiec, 1965):

gdzie:

$$
W_{s}=\frac{\sum_{j=1}^{p} y_{i j}}{p}
$$

$W_{s}$ - wskaźnik syntetyczny,

$j-1,2, \ldots, p$,

p - liczba uwzględnionych cech,

$y_{i j}$ - standaryzowana wartość $j$-tej cechy dla $i$-tego obiektu.

Zastosowanie wskaźnika syntetycznego wymagało w pierwszej kolejności standaryzacji wartości wskaźników opisujących natężenie poszczególnych cech. Standaryzację dla cech mających charakter stymulant przeprowadzono w oparciu o formułę:

$$
y_{i j}=\frac{x_{i j}-\bar{x}}{S_{j}}
$$

gdzie:

$y_{i j}$ - standaryzowana wartość $j$-tej cechy dla $i$-tego obiektu,

$x_{i j}$ - wartość $j$-tej cechy dla $i$-tego obiektu,

$\bar{x}$ - średnia arytmetyczna wartości $j$-tej cechy,

$S_{j}$ - odchylenie standardowe wartości $j$-tej cechy.

Standaryzacja wartości wskaźników doprowadziła do uzyskania macierzy zmiennych standaryzowanych, które wykorzystano przy obliczaniu wskaźników syntetycznych (WS) dla 2014 roku. Na podstawie rozpiętości wartości wskaźników syntetycznych określono skalę zróżnicowania występującego w poziomie rozwoju nowoczesnych usług w wybranych państwach europejskich.

W analizie zróżnicowania przestrzennego poziomu rozwoju nowoczesnych usług w wybranych państwach Europy zastosowano wskaźnik sumaryczny poziomu rozwoju nowoczesnych usług (WS) oraz wskaźniki cząstkowe (WC1, WC2, WC3, WC4, WC5), odpowiadające pięciu wyróżnionym rodzajom nowoczesnych usług: edukacyjnych, medycznych, badawczo-rozwojowych, profesjonalnych (dla biznesu) i finansowych. Wyniki klasyfikacji państw europejskich według wartości wskaźnika syntetycznego poziomu rozwoju usług nowoczesnych prezentuje kartogram (ryc. 2) i tabela 3. Najwyższy poziom rozwoju usług nowoczesnych cechuje państwa skandynawskie: Szwecję, Finlandię i Danię, oraz Luksemburg. Wysokie wartości wskaźnika syntetycznego odnotowano także w Belgii, Holandii, Austrii i Niemczech oraz Irlandii. W przypadku państw skandynawskich o ich wysokiej pozycji zadecydował wysoki poziom rozwoju usług badawczo-rozwojowych, edukacyjnych i usług dla biznesu. Niemcy i Austria natomiast cechują się wysokim poziomem rozwoju usług medycznych. Niekwestionowanym liderem w zakresie poziomu rozwoju usług finansowych jest Luksemburg. Najniższy poziom rozwoju nowoczesnych usług charakteryzuje państwa Europy Środkowo-Wschodniej - Rumunię, Bułgarię oraz Polskę, Węgry i Słowację.

1 Wskaźnik Perkala do oceny potencjału innowacyjnego województw wykorzystali m.in. A. Nowakowska, M. Feltynowski (2009). 
Ryc. 1. Poziom rozwoju usług nowoczesnych w krajach UE w 2014 roku

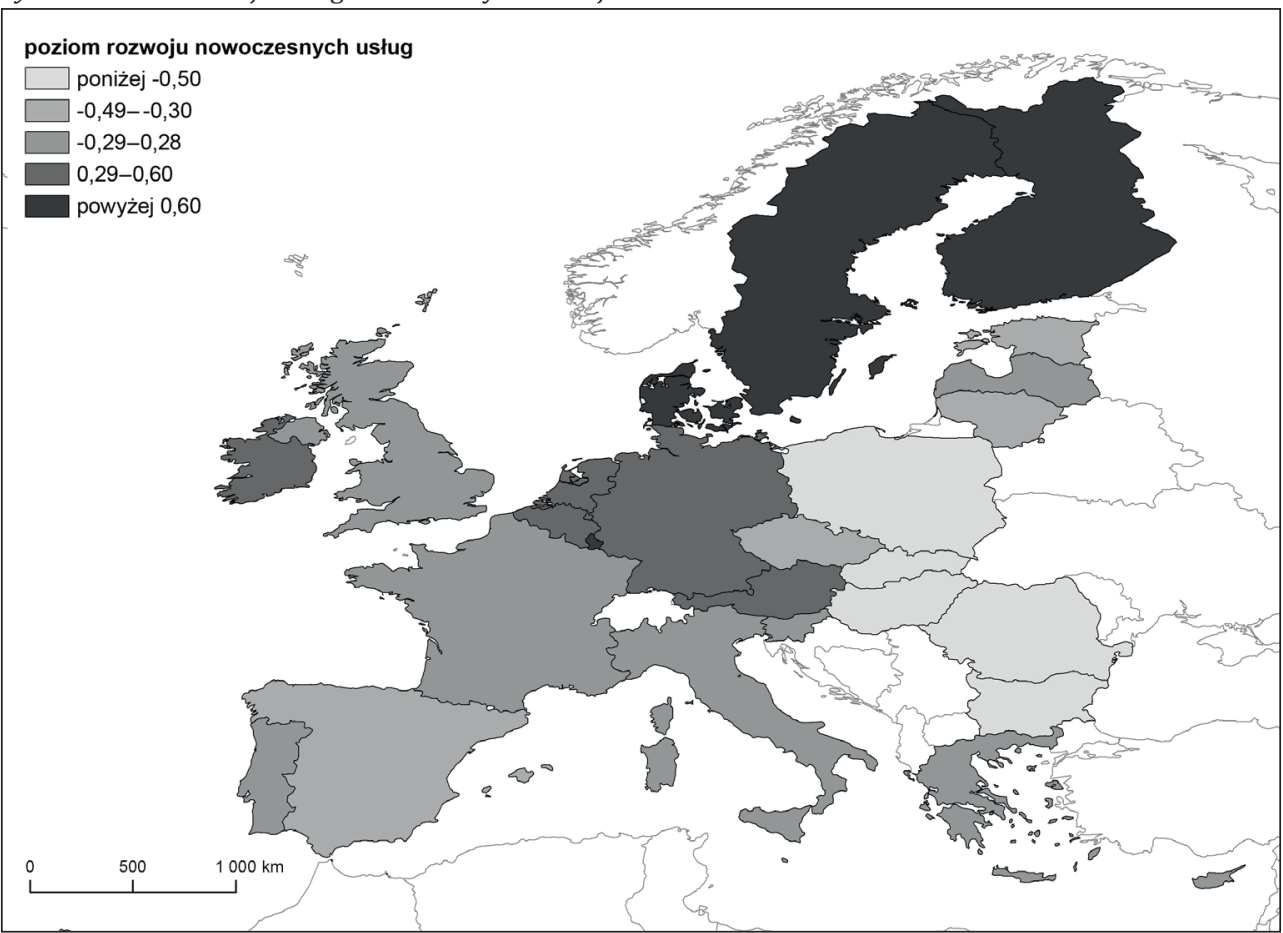

Źródło: opracowanie własne na podstawie danych z bazy Eurostatu (2017)

Tab. 3. Państwa o najwyższym i najniższym poziomie rozwoju wybranych usług nowoczesnych

\begin{tabular}{|l|l|l|l|l|l|}
\cline { 2 - 6 } \multicolumn{1}{l|}{} & \multicolumn{1}{c|}{$\begin{array}{c}\text { Usługi } \\
\text { edukacyjne }\end{array}$} & \multicolumn{1}{c|}{$\begin{array}{c}\text { Usługi } \\
\text { medyczne }\end{array}$} & $\begin{array}{c}\text { Usługi } \\
\text { badawczo- } \\
\text {-rozwojowe }\end{array}$ & \multicolumn{1}{|c|}{$\begin{array}{c}\text { Usługi } \\
\text { finansowe }\end{array}$} & \multicolumn{1}{c|}{$\begin{array}{c}\text { Usługi } \\
\text { dla biznesu }\end{array}$} \\
\hline $\begin{array}{l}\text { Najwyższy poziom } \\
\text { rozwoju }\end{array}$ & $\begin{array}{l}\text { Szwecja } \\
\text { Dania } \\
\text { Finlandia }\end{array}$ & $\begin{array}{l}\text { Szwecja } \\
\text { Austria } \\
\text { Niemcy }\end{array}$ & $\begin{array}{l}\text { Dania } \\
\text { Szwecja } \\
\text { Finlandia } \\
\text { Austria }\end{array}$ & Luksemburg & $\begin{array}{l}\text { Szwecja } \\
\text { Finlandia } \\
\text { Wielka } \\
\text { Brytania }\end{array}$ \\
\hline $\begin{array}{l}\text { Najniższy poziom } \\
\text { rozwoju }\end{array}$ & $\begin{array}{l}\text { Słowacja } \\
\text { Rumunia } \\
\text { Bułgaria }\end{array}$ & $\begin{array}{l}\text { Węgry } \\
\text { Rumunia } \\
\text { Polska }\end{array}$ & $\begin{array}{l}\text { Polska } \\
\text { Cypr } \\
\text { Bułgaria } \\
\text { Rumunia }\end{array}$ & $\begin{array}{l}\text { Słowacja } \\
\text { Estonia } \\
\text { Litwa } \\
\text { Rumunia }\end{array}$ & $\begin{array}{l}\text { Słowacja } \\
\text { Polska } \\
\text { Litwa } \\
\text { Rumunia }\end{array}$ \\
\hline
\end{tabular}

Źródło: opracowanie własne na podstawie danych z bazy Eurostatu (2017)

\section{Poziom RozWoju NOWOCZESNYCH USŁUG W POLSCE - ZRÓżNiCOWANIE REGIONALNE}

W analizie poziomu rozwoju nowoczesnych usług w Polsce w układzie województw zastosowano nieznacznie zmodyfikowany zestaw wskaźników, wymuszony m.in. dostępnością danych statystycznych. Zestaw cech wykorzystanych do analizy zawiera tabela 4. Dane te pochodzą z Głównego Urzędu Statystycznego i dotyczą lat 2015/2016. 
Tab. 4. Wskaźniki poziomu rozwoju nowoczesnych usług

\begin{tabular}{|l|l|}
\hline Rodzaj usług & \multicolumn{1}{|c|}{ Wskaźniki działalności usługowej } \\
\hline $\begin{array}{l}\text { Usługi } \\
\text { edukacyjne } \\
\text { i medyczne } \\
\text { (publiczne) }\end{array}$ & $\begin{array}{l}\text { odsaźnik skolaryzacji (szkoły wyższe) } \\
\text { odsetek ostudentów powyżej 25 roku życia biorących udział w kształceniu (LL) } \\
\text { odsetek nauczycieli w aktywnych zawodowo } \\
\text { liczba nauczycieli akademickich na 10 tys. mieszkańców } \\
\text { odsetek uczniów i studentów wszystkich szczebli edukacji w ogólnej liczbie mieszkańców } \\
\text { liczba lekarzy na 1 tys. mieszkańców }\end{array}$ \\
\hline $\begin{array}{l}\text { Usługi } \\
\text { badawczo- } \\
\text {-rozwojowe }\end{array}$ & $\begin{array}{l}\text { nakłady wewnętrzne na B+R w relacji do PKB } \\
\text { nakłady wewnętrzne przedsiębiorstw na B+R w relacji do PKB } \\
\text { nakłady wewnętrzne na B+R na 1 mieszkańca } \\
\text { odsetek pracujących w B+R na 1 tys. aktywnych zawodowo } \\
\text { jednostki B+R na 10 tys. podmiotów gospodarczych }\end{array}$ \\
\hline $\begin{array}{l}\text { Usługi } \\
\text { profesjonalne } \\
\text { i finansowe }\end{array}$ & $\begin{array}{l}\text { odsetek pracujących w sekcji K PKD 2007 (działalność finansowa i ubezpieczeniowa) } \\
\text { liczba firm sektora finansowo-ubezpieczeniowego na 1 tys. podmiotów gospodarczych } \\
\text { odsetek zatrudnionych w usługach profesjonalnych (sekcja M PKD 2007) } \\
\text { liczba firm świadczących usługi dla biznesu (sekcje L i M PKD 2007) na 1 tys. podmiotów } \\
\text { gospodarczych }\end{array}$ \\
\hline
\end{tabular}

Źródło: opracowanie własne na podstawie danych GUS (2017)

\section{Wyniki przeprowadzonej analizy przedstawiono na rycinach 2 i 3 .}

Ryc. 2. Poziom rozwoju usług wybranych grup usług nowoczesnych w 2015 roku w układzie regionalnym

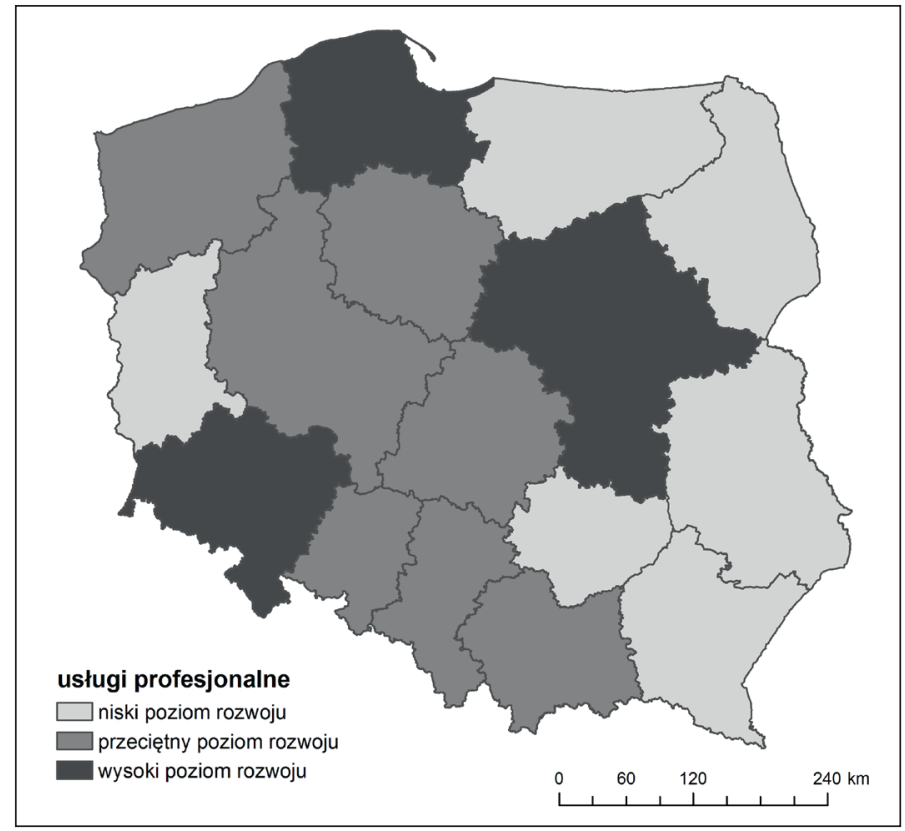

usługi profesjonalne 


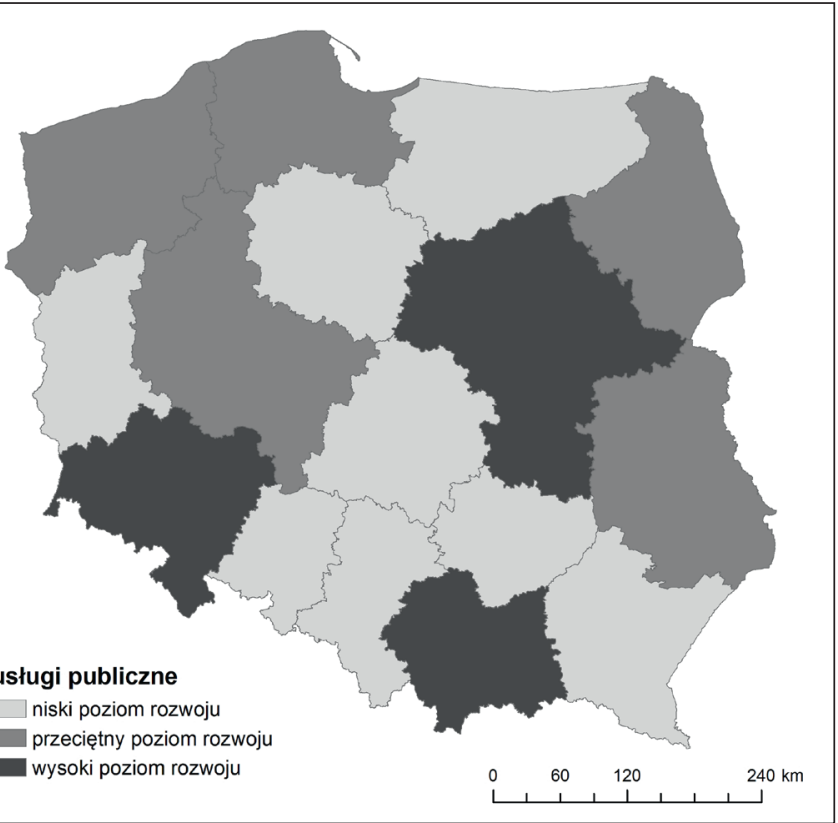

usługi publiczne

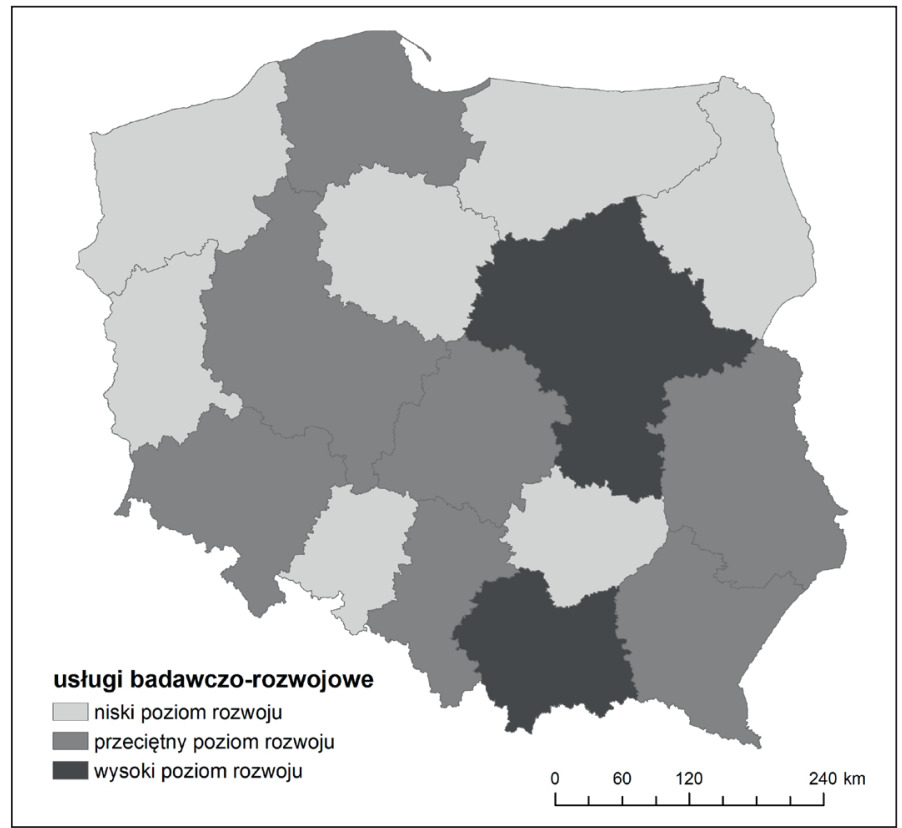

usługi badawczo-rozwojowe

Źródło: opracowanie własne na podstawie danych GUS (2017) 
W każdej z trzech analizowanych grup usług (profesjonalnych i finansowych, badawczo-rozwojowych oraz edukacyjnych i medycznych) do klasy województw o wysokim poziomie rozwoju zaliczono województwo mazowieckie. Jego pozycja w stosunku do pozostałych województw była szczególnie wysoka w przypadku usług profesjonalnych i badawczo-rozwojowych. Jedynie w odniesieniu do usług edukacyjnych i medycznych województwo mazowieckie zostało wyprzedzone przez województwo małopolskie. Na wysoką pozycję województwa małopolskiego miał wpływ wysoki odsetek studentów (szczególnie kierunków technicznych) oraz udział nauczycieli w ogólnej liczbie aktywnych zawodowo. W przypadku usług edukacyjnych - poza województwami mazowieckim i małopolskim - w klasie wysokiego poziomu rozwoju znalazło się także województwo dolnośląskie.

W klasie usług profesjonalnych i finansowych - poza województwem mazowieckim - wysokim poziomem rozwoju wyróżniały się także województwa: dolnośląskie oraz pomorskie. Dominacja województwa mazowieckiego uwidacznia się zwłaszcza w zakresie usług finansowych i ubezpieczeniowych oraz sektora ICT. Natomiast biorąc pod uwagę wskaźnik liczby firm świadczących usługi dla biznesu (poza sektorem ICT oraz finansowo-ubezpieczeniowym), wyższą pozycję odnotowano w przypadku województwa dolnośląskiego. Najwyższym poziomem rozwoju usług badawczo-rozwojowych cechowały się województwa: mazowieckie i małopolskie. Przewaga województwa mazowieckiego wynikała przede wszystkim z wysokich wartości wskaźników finansowych (nakłady na działalność B+R).

Tab. 5. Wartości wskaźnika syntetycznego Perkala dla analizowanych grup nowoczesnych usług w województwach

\begin{tabular}{|l|c|c|c|}
\hline \multicolumn{1}{|c|}{ Województwo } & Usługi profesjonalne & Usługi B+R & Usługi publiczne \\
\hline świętokrzyskie & $-0,93$ & $-0,49$ & $-0,66$ \\
\hline podkarpackie & $-0,73$ & 0,28 & $-0,78$ \\
\hline lubuskie & $-0,64$ & $-0,98$ & $-0,40$ \\
\hline lubelskie & $-0,58$ & 0,02 & 0,21 \\
\hline podlaskie & $-0,47$ & $-0,34$ & 0,12 \\
\hline warmińsko-mazurskie & $-0,47$ & $-0,78$ & $-0,20$ \\
\hline zachodniopomorskie & $-0,39$ & $-0,97$ & 0,21 \\
\hline kujawsko-pomorskie & $-0,29$ & $-0,38$ & $-0,08$ \\
\hline opolskie & $-0,22$ & $-0,47$ & $-0,41$ \\
\hline łódzkie & $-0,21$ & $-0,10$ & $-0,29$ \\
\hline wielkopolskie & $-0,09$ & 0,13 & 0,09 \\
\hline śląskie & 0,29 & $-0,02$ & $-0,19$ \\
\hline małopolskie & 0,31 & 1,05 & 0,95 \\
\hline pomorskie & 0,49 & 0,30 & 0,22 \\
\hline dolnośląskie & 0,92 & 0,24 & 0,57 \\
\hline mazowieckie & 2,50 & 2,09 & 0,53 \\
\hline
\end{tabular}

Źródło: opracowanie własne na podstawie danych GUS (2017)

W klasie przeciętnego poziomu rozwoju w każdej kategorii usług nowoczesnych znalazły się województwa wielkopolskie i śląskie. Pozostałe zmieniały się w zależności od analizowanej kategorii usług. 
Ryc. 3. Poziom rozwoju nowoczesnych usług w Polsce w 2015 roku - zróżnicowanie regionalne

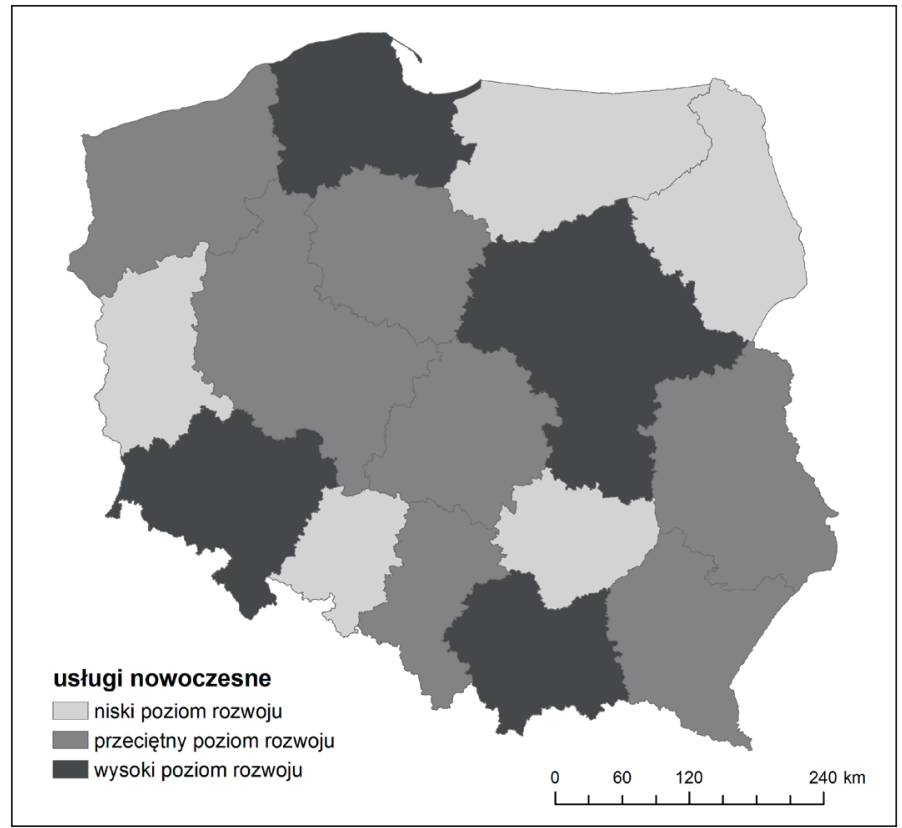

Źródło: opracowanie własne na podstawie danych GUS (2017)

Niskim poziomem rozwoju usług nowoczesnych cechowały się przede wszystkim województwa: lubuskie, świętokrzyskie i warmińsko-mazurskie, które znalazły się w tej klasie we wszystkich analizowanych rodzajach usług. W zakresie usług edukacyjnych i medycznych najniższe wartości wskaźnika syntetycznego odnotowano w województwach: podkarpackim, świętokrzyskim i opolskim. W zakresie usług profesjonalnych i finansowych najniższą pozycję zajmowały województwa: świętokrzyskie, podkarpackie i lubuskie, natomiast w odniesieniu do usług badawczo-rozwojowych województwa: lubuskie, zachodniopomorskie i warmińsko-mazurskie.

\section{PodsumOWANIE}

W ujęciu całościowym wysokim poziomem rozwoju usług nowoczesnych charakteryzują się województwa: mazowieckie, małopolskie, dolnośląskie i pomorskie. Wysoka pozycja województwa mazowieckiego jest wynikiem najwyższej jego pozycji w większości analizowanych kategorii usług nowoczesnych (poza edukacyjnymi i medycznymi). Województwo małopolskie znalazło się w tej klasie głównie za sprawą wysokiego poziomu rozwoju usług edukacyjnych i badawczo-rozwojowych, a województwa dolnośląskie i pomorskie - dzięki usługom profesjonalnym. Niskim poziomem usług nowoczesnych cechują się przede wszystkim słabe gospodarczo województwa Polski Wschodniej oraz województwa: lubuskie, świętokrzyskie i opolskie.

Regionalny rozkład wartości wskaźnika syntetycznego poziomu rozwoju usług nowoczesnych w wyraźny sposób nawiązuje do rozkładu ogólnego poziomu rozwoju społeczno-gospodarczego województw. Województwa cechujące się wysokim poziomem rozwoju społeczno-gospodarczego wykazują także ponadprzeciętny poziom rozwoju 
usług nowoczesnych, szczególnie w odniesieniu do usług profesjonalnych i badawczo-rozwojowych. Szczegółowe potwierdzenie tej relacji wymaga jednak dodatkowych badań (Dominiak, 2017).

\section{Literatura}

\section{References}

Den Hertog, P., Bilderbeek, R.. (1999). Conceptualising Service Innovation and Service Innovation Patterns. Research Programme on Innovation in Services (SIID) for the Ministry of Economic Affairs. Utrecht.

Dominiak, J. (2017). Nowoczesne usługi a poziom rozwoju gospodarczego. W: Z. Zioło, T. Rachwał (red.). Przemiany strukturalne wybranych sektorów gospodarki. Prace Komisji Geografii Przemysłu Polskiego Towarzystwa Geograficznego, 31(1), 81-96.

Eichengreen, B., Gupta, P. (2009). The two waves of service sector growth. Cambridge: The National Bureau of Economic Research.

Eurostat (2017, 18 grudnia). Pozyskano z http://ec.europa.eu/eurostat

Garcia, R., Calantone, R. (2002). A Critical Look at Technological Innovation Typology and Innovativeness Terminology: A Literature Review. Journal of Product Innovation Management, 19, 110-132.

GUS (2017, 18 grudnia). Pozyskano z http://stat.gov.pl/

Johnson, S., Menor, L., Roth, A., Chase, R. (2000). A Critical Evaluation of the New Service Development Process: Integrating Service Innovation and Service Design. W: J. Fitzsimmons, M. Fitzsimmons (red.). New Service Development: Creating Memorable Experiences. Thousand Oaks: Sage Publications, 1-32.

Kostrubiec, B. (1965). Klasyfikacja dynamiczna i wielocechowa województw Polski. Biuletyn Komitetu Przestrzennego Zagospodarowania Kraju Polskiej Akademii Nauk, 35.

Menor, L., Tatikonda, M., Sampson, S. (2002). New service development: areas for exploitation and exploration. Journal of Operations Management, 20(2), 135-157.

Mishra, S., Lundstromm, S., Anand, R. (2011). Service Export Sophistication and Economic Growth. World Bank. Policy Research Working Paper, 5606.

Nowakowska, A., Feltynowski, M. (2009). Metoda oceny potencjału innowacyjnego regionów. W: A. Nowakowska (red.). Zdolności innowacyjne polskich regionów. Łódź: Wydawnictwo Uniwersytetu Łódzkiego, 11-23.

Rogoziński, K. (2004). Innowacyjność i nowa taksonomia usług. Wiadomości Statystyczne, 3.

Runge, J. (2007). Metody badań w geografii społeczno-ekonomicznej - elementy metodologii, wybrane narzędzia badawcze. Katowice: Wydawnictwo Uniwersytetu Śląskiego.

Soete, L., Miozzo, M. (1989). Trade and Development in Services: A Technological Perspective. Maastricht: UNU-MERIT.

Szukalski, S.M. (2001). Sektor usług w gospodarce niemieckiej. Hipotezy i empiryczna weryfikacja przekształceń strukturalnych. Łódź: Wydawnictwo Uniwersytetu Łódzkiego.

Joanna Dominiak, dr, adiunkt w Zakładzie Analizy Regionalnej Instytutu Geografii Społeczno-Ekonomicznej i Gospodarki Przestrzennej Uniwersytetu im. Adama Mickiewicza w Poznaniu. Zainteresowania naukowe koncentrują się wokół roli innowacyjności w kształtowaniu gospodarki opartej na wiedzy, wpływu otoczenia biznesu na rozwój regionów oraz przemian w strukturze usług.

Joanna Dominiak, Ph.D., assistant professor in the Regional Analysis Department in the Institute of Socio-Economic Geography and Spatial Management of Adam Mickiewicz University in Poznan. Research interests revolve around the role of innovation in the development of the knowledge-based economy, the impact of the business environment on the development of regions and changes in the structure of services.

\section{Adres/address:}

Uniwersytet im. A. Mickiewicza w Poznaniu Instytut Geografii Społeczno-Ekonomicznej i Gospodarki Przestrzennej

Zakład Analizy Regionalnej

ul. Dzięgielowa 27, 61-680 Poznań, Polska

e-mail: dominiak@amu.edu.pl 